\title{
SMART CITY CONCEPT IN THE LIGHT OF THE LITERATURE REVIEW
}

pages: $70-86$

\author{
Justyna Winkowska, DanUta SzPILKo, SONJA PEJić
}

\begin{abstract}
A B S T R A C T
Nowadays, the transformations of metropolises into smart cities is a crucial factor in improving the living conditions of the inhabitants. The goal of the smart city concept is modern urban management using technical tools that offer state-of-the-art technologies, considering the applicable ecological standards while saving resources and achieving the expected results. The purpose of this article is to identify the areas of research analysed in the international literature in the field of smart cities. The bibliometric analysis was carried out to achieve the purpose. The analysis covered publications on smart cities published in Scopus and Web of Science databases from January 2009 to May 2019. Based on the bibliometric analysis, a bibliometric map was developed using the mapping technique VOS - the visualisation of similarities. Original clusters were created using the VOSviewer software. The bibliometric map visualises the results of the analysis that targeted the word coexistence.
\end{abstract}

KEY WORDS

smart city, smart city subareas, bibliometric map

DOI: 10.2478/emj-2019-0012
Corresponding author:

Justyna Winkowska

Bialystok University of Technology, Poland e-mail: j.winkowska@pb.edu.pl

Danuta Szpilko

Bialystok University of Technology, Poland e-mail: d.szpilko@pb.edu.pl

Sonja Pejić

University of Novi Sad, Serbia e-mail: anael@uns.ac.rs

\section{INTRODUCTION}

A city appears to be an obvious concept only when it is a secondary subject of research and is used as a relatively obvious context. As soon as it becomes the centre of interests, the focus should be not so much on precise and unambiguous definitions but functional conceptualisations (Matyja, 2017). A contemporary city is perceived as a socio-economic sys- tem. It is characterised by the complexity of many elements and their interrelations that integrate the city's components so that it can function and develop (Stawasz \& Sikora-Fernandez, 2015). Urban development is determined by the constantly increasing migration of people from rural areas to urbanised areas. In $2018,55 \%$ of the global population lived in urban areas. According to forecasts developed by the 
Population Division of the United Nations Department of Economic and Social Affairs (UN DESA), in 2050 , this share will increase to $68 \%$. The global urban population in 2018 was 4.2 billion. Increasing urbanisation and gradual migration of people from rural to urban areas, combined with the general increase in the global population, means that by 2050 , urban areas will accommodate another 2.5 billion people (nearly $90 \%$ of this increase will take place in Asia and Africa) (United Nations, 2018). Based on the forecasts, the next few decades should see cities undergoing constant changes, including in their structures. With the expected increase in the number of urban residents around the world, the need is growing for new and innovative ways to manage the complexity of urban life.

Considering the growing importance of cities in the development of many regions and countries, supported each year by the increasing number of smart city initiatives, the authors conducted a bibliographic analysis of the existing publications in this area, collected in Scopus and Web of Science databases. The article aims to identify the areas of research analysed in the literature concerning a smart city. This measure represents the first stage of the research process, aiming to identify the research problems in the field and a solution, which would constitute a theoretical and practical contribution to the development of smart city management.

All the considerations and research in the field of discussed issues are included in four chapters. The first chapter presents a general approach to the conditions of contemporary cities and presents smart city concepts. Next, the methodology used for bibliometric analysis is described. The third chapter is devoted to the results of the conducted bibliometric analysis. The last part of the work analyses the obtained results and presents the conclusions.

\section{LITERATURE REVIEW}

Intensive development, which is undoubtedly a challenge for modern cities, can give rise to positive outcomes for urban communities as well as negatively affect the smooth functioning of the city. The challenges of modern cities are centred around:

- uncontrolled urban sprawl (Kovács et al., 2019; Halmy, 2019; Yu et al., 2019; Mahmoud \& Divigalpitiya, 2019);
- environmental pollution (Caparros-Midwood et al., 2019; Alam et al., 2019; Munoz-Pandiella et al., 2018; Kosheleva et al., 2018);

- urban logistics (Nataraj et al., 2019; Firdausiyah et al., 2019; Bjørgen et al., 2019; Cleophas et al., 2019; Faramehr et al., 2019; Mesjasz-Lech, 2014; Tomaszewska \& Florea, 2018);

- technical infrastructure (Petrova \& Prodromidou, 2019; Faramehr et al., 2019; Pham \& Phan, 2018; Juget \& Ryckewaert, 2018);

- waste management (Bugge et al., 2019; Amritha \& Kumar, 2019; Dlamini et al., 2019; Scorţar et al., 2010);

- aging population (Jayantha et al., 2018; Fang \& Lai, 2018; Onoda, 2018; Greenfield, 2018; Jarocka \& Wang, 2018);

- stratification of wealth levels, areas of poverty (Muktiali, 2018; Lanjouw \& Marra, 2018; Ma et al., 2018; Aguilar \& López, 2016);

- low level of citizen participation in the management of public affairs (Mavrodieva et al., 2019; Sou, 2019; van Holm, 2019; de Castro Pena et al., 2017).

Knowing the identified challenges and the expected increase in the number of urban residents around the world, there is an increasing need for new and innovative ways to manage the complexity of urban life. In the last decade, the smart city concept has gained considerable popularity, ultimately enabling residents to better meet their housing, transport, energy and other infrastructure needs, but also as a key strategy to combat poverty and inequality, unemployment and energy management. The smart city concept assumes that a city should be a creative, sustainable area that improves the quality of life, creates a friendlier environment and the prospects of economic development are stronger (Lee et al., 2014). Intelligence as a distinguishing feature of this type of a city, should not be treated in the literal sense of the word but perceived as the sum of various improvements in urban infrastructure, resources and public services (Allwinkle \& Cruickshank, 2011). Although there is no formal and widely accepted definition of a "smart city", the ultimate goal is a better use of public resources, the improvement of the quality of services offered to citizens, while reducing operational costs of public administration (Zanella et al., 2014). It is understood that cities can be defined as smart if they have the following elements (Fig. 1).

The smart economy is measured by entrepreneurship and a city's productivity, adaptation to changes, the flexibility of the labour market and 


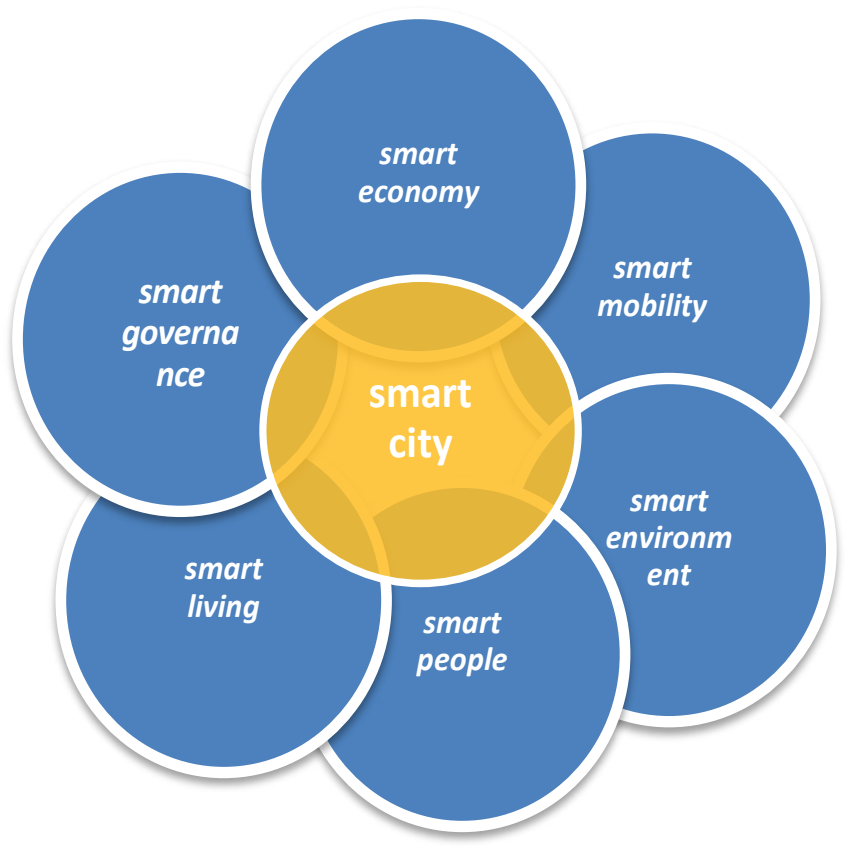

Fig. 1. Smart city elements

Source: elaborated by the authors based on (Stawasz \& Sikora-Fernandez, 2016; Zanella et al., 2014; Caragliu et al., 2011).

international cooperation. Smart mobility is perceived by the accessibility of information and communication infrastructure, through the development of sustainable, innovative and safe transport. The smart environment is measured by the attractiveness of the natural environment, pollution levels, environmental protection activities and resource management methods.

Smart people are characterised by the level of qualifications, lifelong learning, social and ethnic diversity, creativity, openness and participation in public life. Smart living is measured by existing cultural facilities, living conditions (health, safety, housing), educational facilities, tourist attractiveness and social cohesion. Smart governance is expressed by the transparency of city management, social participation, the level of public services and the implementation of development strategies (Stawasz \& Sikora-Fernandez, 2016; Zanella et al., 2014; Caragliu et al., 2011).

Many authors have attempted to formulate the definition of a "smart city" by binding it with different terms, which is indicative of the lack of a uniform or widely accepted definition (Schaffers et al., 2012; Zhuhadat et al., 2017; Chong et al., 2018). In publications dealing with the subject of a "smart city", there are many alternative terms for this concept, such as: "digital city" (Tan, 1999), "wired city" (Targowski, 1990), "information city" (Fietkiewicz et al., 2017;
Sproull \& Patterson, 2004; Stolfi \& Sussman, 2001), "ubiquitous city" (Shin, 2009), "sensing city" (Mone, 2015). When reviewing the literature, it was noticed that in the vast majority of publications, authors attempting to define the concept of a "smart city" focused on the technological aspect. For example, Peng, Nunes and Zheng (2017) defined a "smart city" as a city using a set of advanced technologies, such as wireless sensors, smart meters, intelligent vehicles, smartphones, mobile networks or data storage technologies. In turn, Guo et al. (2017) claimed that a "smart city" is urban development based on the integration of many information and communication technology (ICT) solutions to manage the city's resources. These definitions of a "smart city" emphasise the role of technology. However, a city can hardly become smart because of technology alone (Nam \& Pardo, 2014). Ortiz-Fournier et al. (2010) included citizens of smart cities in the definition of a "smart city". The authors described a "smart city" in the context of its intelligent inhabitants, the quality of social interactions, and integration with public life. In the current perception of the "smart city" concept, there is a return to the needs and preferences of the inhabitants, which are the focus. Thus, technical solutions should serve their interests. Residents, their specific features and abilities are the basis of a modern city (Mizielińska-Chmielewska, 2018). As rightly noted by Noworól (2011), the local government 
should base their activities on the value system and focus on creating a vision of the future of the city. Szołtysek and Otręba (2015) added that the efficient preparation and implementation of activities were closely related to the need to recognise the feelings and emotions of all groups of residents, which should serve as a basis for efficient city management programmes. Huang, Zhang and Wang (2017) also emphasised aspects of city management. They defined a city as smart if it was managed in intelligently, efficiently and sustainably. According to the assumptions of Manville et al. (2014), a "smart city" is a city where public issues are solved using ICT, with the involvement of various types of stakeholders working in partnership with the city authorities.

As noted by Molpeceres Arnáiz (2017), according to some business and political discourses, a smart city seems to be the city of the future. However, despite the numerous potential amenities of a "smart city" that cities could draw from, there are some barriers that make the implementation of this concept difficult (Dohler et al., 2011). Among the difficulties that arise when implementing the "smart city" concept, several stand out (Ravetz, 2017; Naphade et al., 2011; Krukowska, 2018; Proseedmag, 2017; What ..., 2018; Sikora-Fernandez, 2017; Bashynska \& Dyskina, 2018):

- $\quad$ excessive concentration on investing in advanced technologies without the real perception of conflicts and problems in cities;

- the deployment of smart technologies in cities with complex social problems can exacerbate social inequalities through technical improvements;

- the lack of implemented solutions to use the local community to co-manage the city;

- the lack of a comprehensive view of cities considering the needs in all areas of their functioning;

- changes related to the introduction of the "smart city" concept, mainly including the technological aspect, may negatively affect the loss of the existing character and unique charm of some agglomerations, especially those valued due to their traditional character;

- the majority of investments in the development of the "smart city" concept focuses on creating new facilities instead of modernising the old ones;

- the development of smart city infrastructure requires huge investments, which are indirectly made by citizens, e.g. in the form of a higher tax rate;
- managing cities is a huge challenge and requires, above all, intelligence, responsibility, and reasonableness, which cannot be replaced by modern technologies and especially building cities from scratch. City innovation is not glass skyscrapers and cosmic architecture, but the creation of the best living and working conditions;

- $\quad$ incompetently or unknowingly used services by so-called digital illiterate people can cause much personal and systemic damage;

- $\quad$ cities equipped with modern technologies, e.g. housing or newly built, do not become an object of interest to the inhabitants due to high maintenance costs and lack of social relationships (e.g. Masdar city or Tianjin Eco-city built in nearby Beijing, where there are no schools, shops, transport to factories where people can work).

Complexity, diversity and uncertainty are the three key attributes of modern cities (FernandezGuell et al., 2016), which hinder the conceptual and technical progress in the implementation of a "smart city". In fact, this concept evolves from the simple integration of technology in the city with the development of solutions for urban challenges in a mutually connected and synergistic way (Lombardi et al., 2012; Mattoni et al., 2015). Processes that support the development, changes and everyday functioning of cities are complex and urban environments should be perceived as such as well, namely, as complex social engineering systems (Elzen et al., 2004). Many publications indicate the need to develop an integrated and holistic approach to a "smart city" (Perboli et al., 2014; Gil-Garcia et al., 2015).

\section{RESEARCH METHODS}

Considering the nature of the publication, which is a review, a bibliometric analysis was used as a research method. The results obtained using the bibliometric analysis are usually presented in the form of a map showing relationships between individual elements (Gudanowska, 2015, 2017; Siderska \& Jadaa, 2018; Szpilko, 2017).

Based on the bibliometric analysis, the assessment of the dynamics of interest in the "smart city" subject was made, which is reflected in the number of publications in Scopus and Web of Science databases in the period from January 2009 to May 2019. In the next step of the research, a bibliometric map was created using the mapping technique VOS - the visualisation of similarities. VOS aims to locate items in 
a low-dimensional space in such a way that the distance between any two items reflects the similarity or relatedness of the items as accurately as possible (Eck \& Waltman, 2011). The map was developed using the VOSviewer program, which is available from www. vosviewer.com. The created map is the reflection of the co-occurrence of words and their co-classification in publications. The size of the wheels on the map reflects the number of specific words, while the distance between the wheels depends on the number of coexistence (Halicka, 2017). The co-word analysis is based on counting the frequency of appearance in the analysed text, a few words. It allows identifying phrasemes or regularities in the coexistence of words. Co-occurrence words can signal the existence of subarea research or identify guideline directions for further development of a given research area. Results of the co-classification analysis allow identifying the sub-areas of research both in one area, as well as in interdisciplinary fields (Dobrzyński et al., 2013). This method enabled the creation of six clusters - the sub-areas of research relating to "smart city" issues.

The basic source of data in a bibliometric analysis is bibliographic databases. A review of the publications was made in Scopus and Web of Science databases. The databases were selected because of their size and availability. In Scopus and Web of Science, it is possible to save data from bibliographic queries in the form of files that can then be directly developed using the bibliographic software VOSviewer. The formulation, based on which the database was searched, was "smart city", including in article titles, abstracts and keywords.

\section{RESEARCH RESULTS}

The exploration of the Scopus database resulted in finding 15744 studies registered in the database, of which the largest part were (Fig. 2) conference papers (63.4\%) and articles (24.5\%). In the Web of Science, authors found 5151 publications, of which the largest part, similarly to Scopus, were (Fig. 3) conference papers (55.6\%) and articles (41.2\%).

The great majority of publications were created in China, the United States, India, Italy, the United Kingdom, Spain, Germany and France. Numerous publications also originated in the Russian Federation, Australia and Japan.

The next step was dedicated to the analysis of the interest in the subject matter over the years. The time frame of the analysed period covered the last ten years from January 2009 to May 2019. The number of studies published in individual years is shown in Fig. 4.

Analysing Fig. 4, it can be noticed that initially - for the first five years - the interest in this subject was not significant. It is only since 2014 that interest in the "smart city" concept clearly increased, which is reflected by the number of publications in the Scopus database. Such dynamic growth in interest in this subject highlights the importance and validity of the subject area. In the next step, the identified publications were analysed in terms of research areas (Figs. 5 and 6).

In the Scopus database, over 34\% of publications related to computer science and almost 19\% to engineering. In the Web of Science, 37\% relate to com-

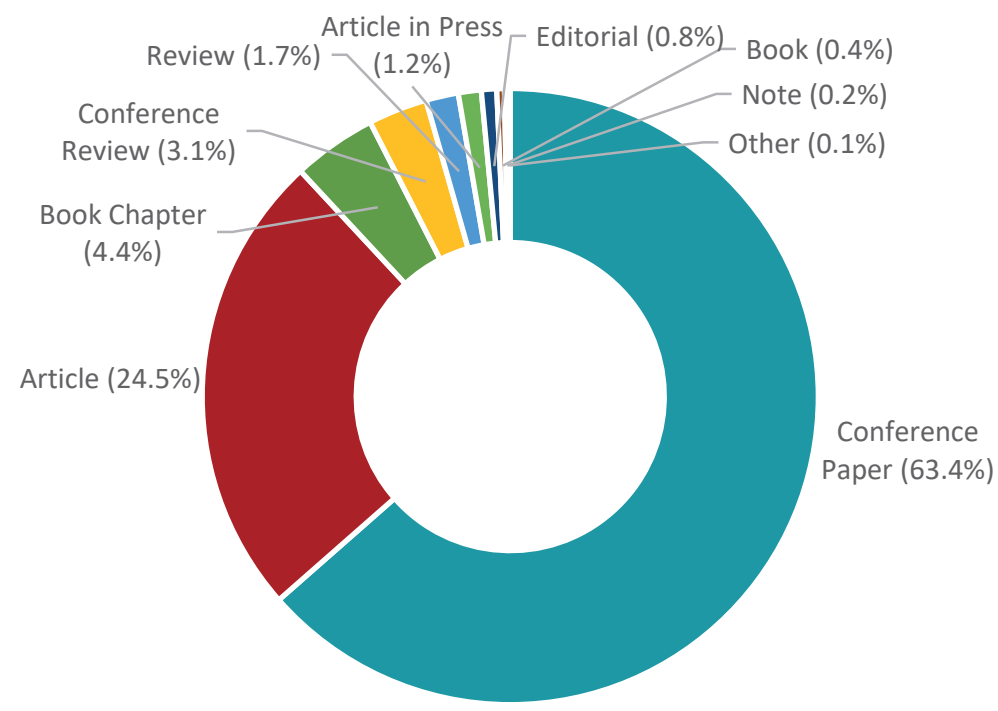

Fig. 2. Results of the search in the Scopus database - the document type criterion (indexed from January 2009 to May 2019) 


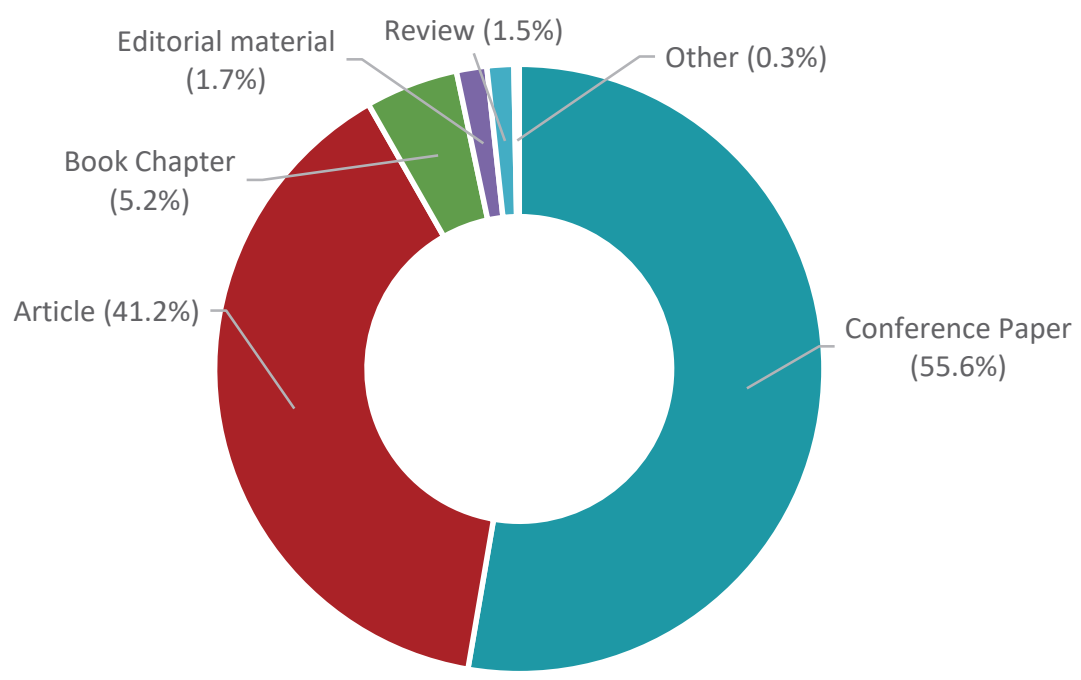

Fig. 3. Results of the search in the Web of Science database - the document type criterion (indexed from January 2009 to May 2019)

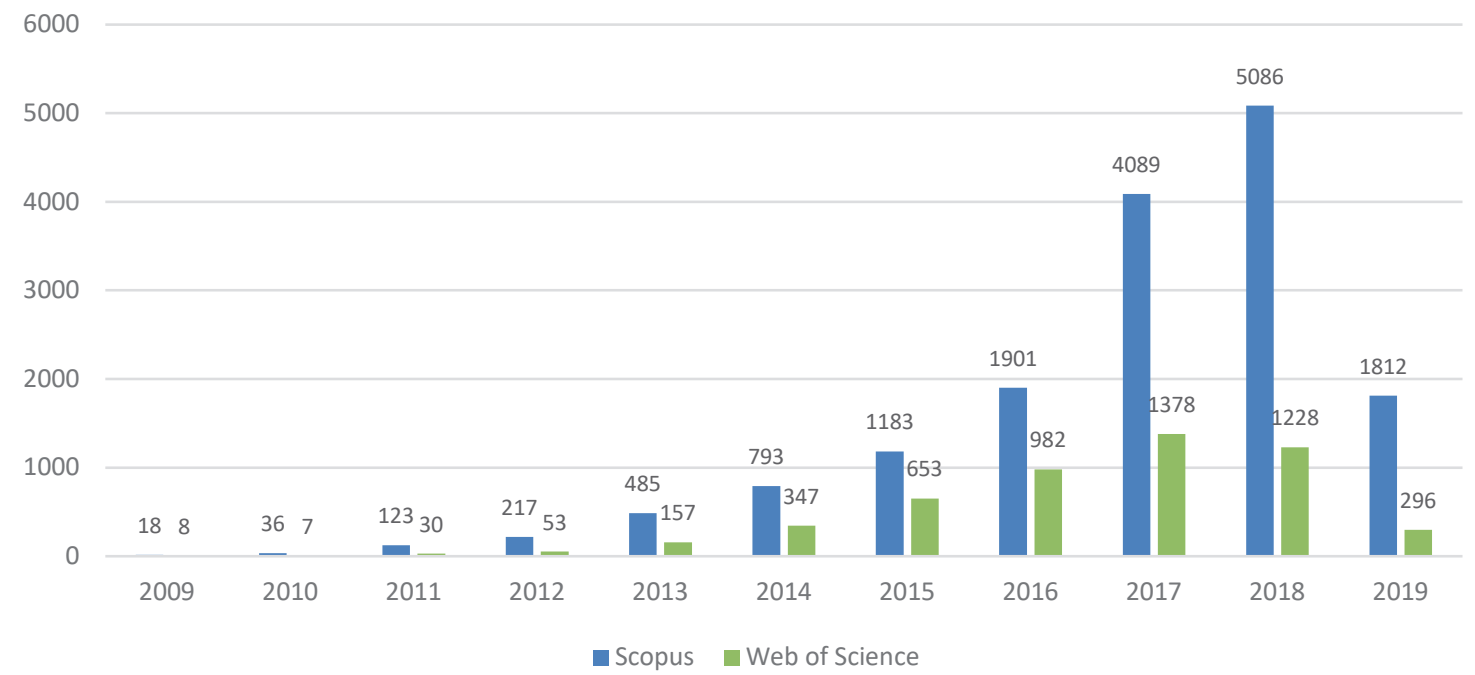

Fig. 4. Number of publications in the field of "smart city" in Scopus and Web of Science databases (indexed from January 2009 to May 2019)

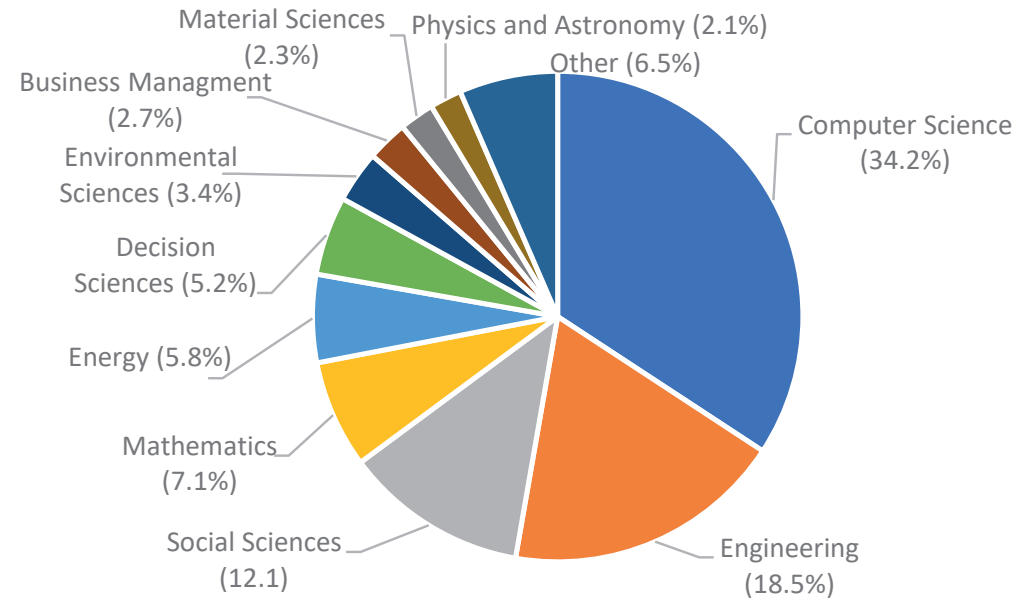

Fig. 5. Identified publications in terms of a subject area (Scopus database, indexed from January 2009 to May 2019) 


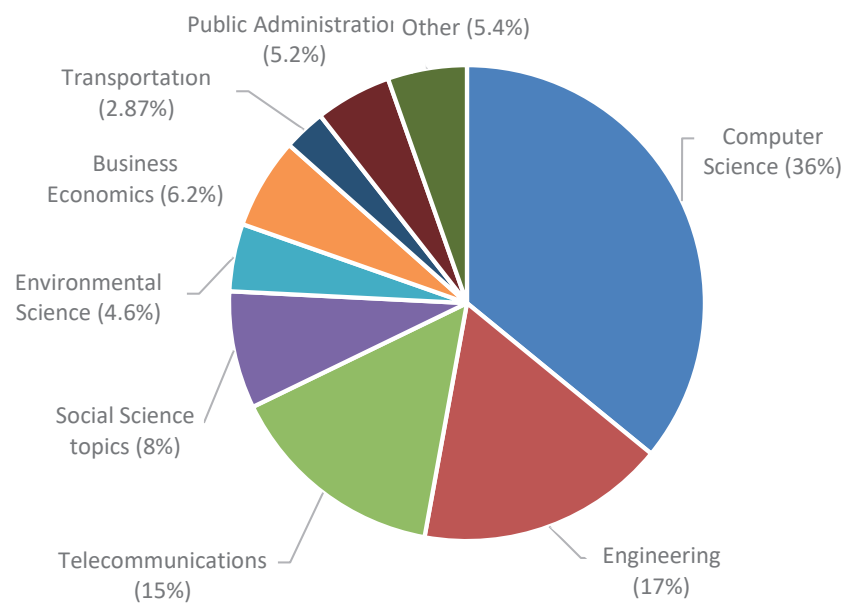

Fig. 6. Identified publications in terms of a subject area (Web of Science database, indexed from January 2009 to May 2019)

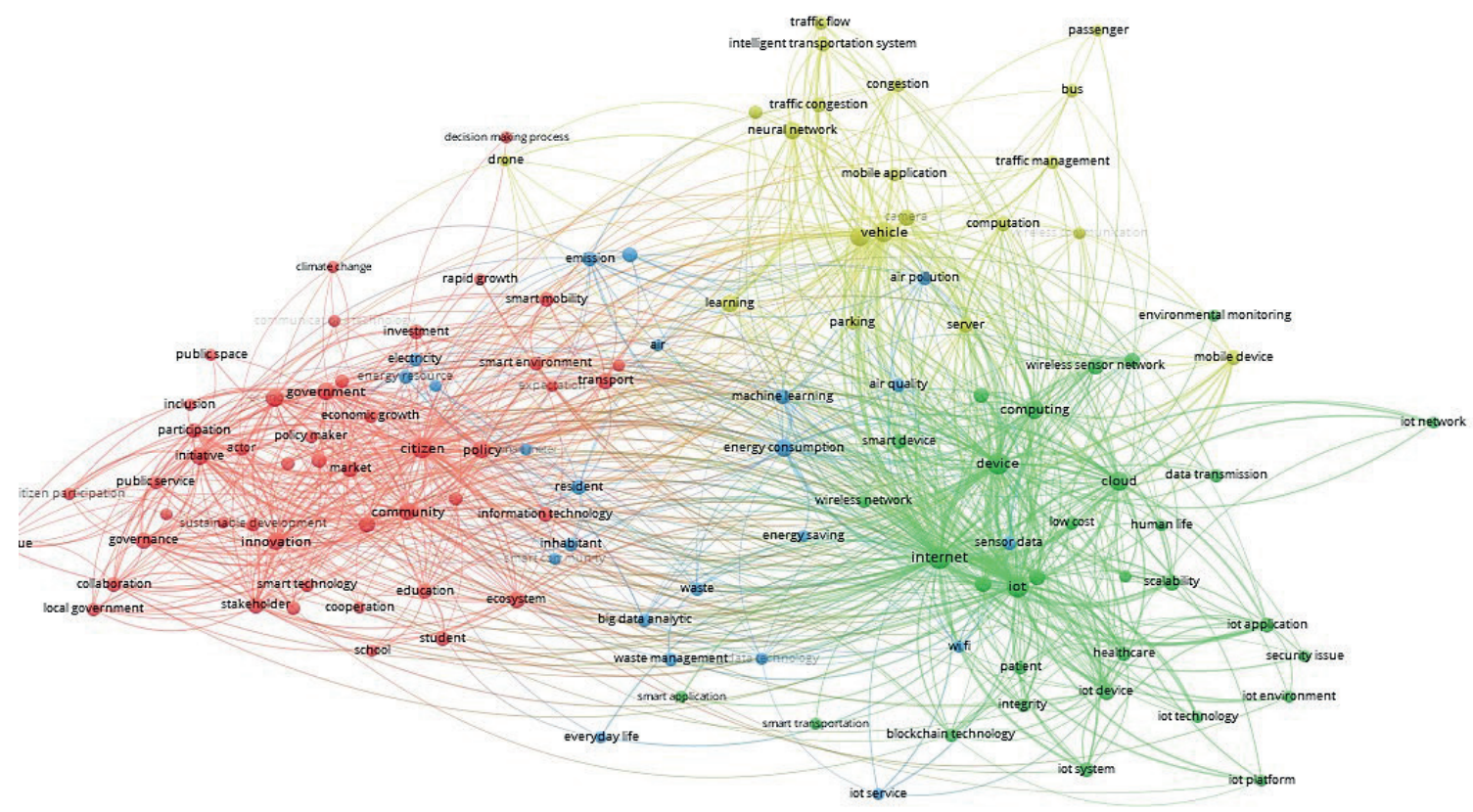

Fig. 7. Map of sub-areas related to the "smart city" concept

puter science and 30\% to engineering. This proves that in most publications, the authors focus on technological aspects, where urban development is based on many IT solutions to manage the city's resources. However, more and more authors, namely, $12.1 \%$ (Scopus), indicate the importance of social aspects in the smart city concept.

In the last stage of the bibliometric analysis, a bibliometric map was developed, which is a visualisation of the results of the analysis regarding the coexistence of words using the VOSviewer software. The results of the analysis are presented in Fig. 7.

The analysis of the coexistence of words made it possible to distinguish six clusters as sub-areas related to the "smart city" concept. When analysing individual clusters, the following names were proposed:

- Cluster 1 - smart technology;

- Cluster 2 - socio-economic aspects;

- Cluster 3 - environmental aspects;

- Cluster 4 - urban logistics.

\section{DISCUSSION OF THE RESULTS}

By making a bibliometric analysis of the smart city concept, a very dynamic increase in the interest of researchers in this field over the last five years has been noticed. The areas addressed by authors in their publications were computer science and engineering. 
Tab. 1. Sub-areas and main issues of smart city research

\begin{tabular}{|c|c|c|}
\hline CLUSTER & RESEARCH SUB-AREAS & MAIN RESEARCH ISSUES \\
\hline 1. & $\begin{array}{l}\text { SOCIO-ECONOMIC } \\
\text { ASPECTS }\end{array}$ & $\begin{array}{l}\text { - } \quad \text { the quality of social interaction (Neuroni et al., 2019; Tenney et al., 2019; Timmer- } \\
\text { man et al., 2019; Adnan et al., 2018; Vhaduri et al., 2018; Oliveira \& Santos, 2018); } \\
\text { the engagement of citizens in public life and decision-making; the participation of } \\
\text { local stakeholders in managing public affairs; the collaboration between the local } \\
\text { government and residents (Novo Vázquez \& Vicente, 2019; Certomà \& Rizzi, 2017; } \\
\text { Streitz, 2017; Morgado et al., 2015; Ma \& Lam, 2019; Horgan \& Dimitrijević, 2019; } \\
\text { Trencher, 2019; Manchester \& Cope, 2019; Kundu, 2019; Mannan \& Callenes- } \\
\text { Sloan, 2019); } \\
\text { - healthcare (Sittón-Candanedo et al., 2019; Kumar et al., 2019; Kamel Boulos et al., } \\
\text { 2019; Sedighian 2019; Chondrogiannis et al., 2019; Julian \& Botti, 2019); } \\
\text { - security issues (Mattos et al., 2019; Krämer et al., 2019; Sittón-Candanedo et al., } \\
\text { 2019; Sharma \& Kalra, 2019; Xie \& Hwang, 2019; Vitunskaite et al., 2019); } \\
\text { education (Sodiq et al., 2019; Fernández et al., 2019; Panchanathan et al., 2019; } \\
\text { Safiullin et al., 2019; Deng, 2019; Li, 2019); } \\
\text { the development of entrepreneurship (Grimaldi et al., 2019; Gonzaga, 2019; } \\
\text { Perng et al., 2018; Tay et al., 2018; Indravati et al., 2018; Carè et al., 2018); }\end{array}$ \\
\hline 2. & URBAN LOGISTICS & $\begin{array}{l}\text { - } \quad \text { congestion (Zhao et al., 2019; Zhu \& Liang, 2019; Yang \& Zhu, 2019; Mishra, 2019; } \\
\text { Reddy \& Mehta, 2019; Garg et al., 2019); } \\
\text { traffic flow management (Zheng et al., 2019; Ferrer et al., 2019; Vranken et al., } \\
\text { 2019; Vaida \& Mouftah, 2019; Chen, 2019; Kuang et al., 2019); } \\
\text { - } \quad \text { autonomous vehicles (Li et al., 2019; Cantas et al., 2019; Schmitt et al., 2019; Ji et } \\
\text { al., 2019; Xie et al., 2019); }\end{array}$ \\
\hline 3. & $\begin{array}{l}\text { ENVIRONMENTAL } \\
\text { ASPECTS }\end{array}$ & $\begin{array}{l}\text { - incorporating sustainable development principles into the smart city concept } \\
\text { (Bibri, 2019; Ismagilova et al., 2019; Allam \& Dhunny, 2019; Zhang \& Pu, 2019; Cao } \\
\text { et al., 2019; Chakrabarty, 2019); }\end{array}$ \\
\hline 4. & SMART TECHNOLOGY & $\begin{array}{l}\text { - } \quad \text { IOT - the Internet of things (Mattos et al., 2019; Sittón-Candanedo et al., 2019; } \\
\text { Heaton \& Parlikad, 2019; Jan et al. 2019; Rath \& Pattanayak, 2019); } \\
\text { cloud computing (Azhdari et al., 2019; Huang et al., 2019; Min-Allah et al., 2019; } \\
\text { Wang et al., 2019; Del Esposte et al., 2019); } \\
\text { - } \quad \text { big data (Kong et al., 2019; Putra et al., 2019; Lakshmanaprabu et al., 2019; Luo et } \\
\text { al., 2019; Ameer et al., 2019); } \\
\text { - artificial intelligence (Khadse et al., 2019; Marcuzzi \& Tonello, 2019; Wei et al., } \\
\text { 2019; Panchamathan et al., 2019; Bui \& Jung, 2019; Hu \& Jiang, 2019); } \\
\text { wireless sensor networks (Sadeghpour et al., 2019; Chammas et al., 2019; Godoi } \\
\text { et al., 2019; Alduais et al., 2019; Marrero et al., 2019; Alchihabi et al., 2019; } \\
\text { Sedighian \& Kashi, 2019) }\end{array}$ \\
\hline
\end{tabular}

This proves that in most publications, authors focused on technological aspects, where urban development was based on the integration of many IT solutions aiming to manage the city's resources. However, more and more authors in their publications indicated the importance of social aspects in the smart city concept. The analysis of the co-occurrence and co-classification of words made it possible to identify four clusters that constitute research sub-areas in the context of the smart city concept. In Tab. 1, research sub-areas of the smart city concept are indicated as well as related emerging research directions and issues.

In the cluster defined as socio-economic aspects, there are elements such as the quality of social inter- action and integration with public life. The important elements are living conditions, for example, healthcare, security and education. The basis of a "smart city" is residents and their needs. In this cluster, the role of inhabitants and local stakeholders stands out, meaning their participation in managing public affairs and decisions making processes. There is a strong need for creating transparent principles of collaboration between local government and residents. Also, no smart city is possible without the well-prospering economy. The key is to develop entrepreneurship and business that would not only function on the local market but internationally as well. Another research sub-area concerns environ- 


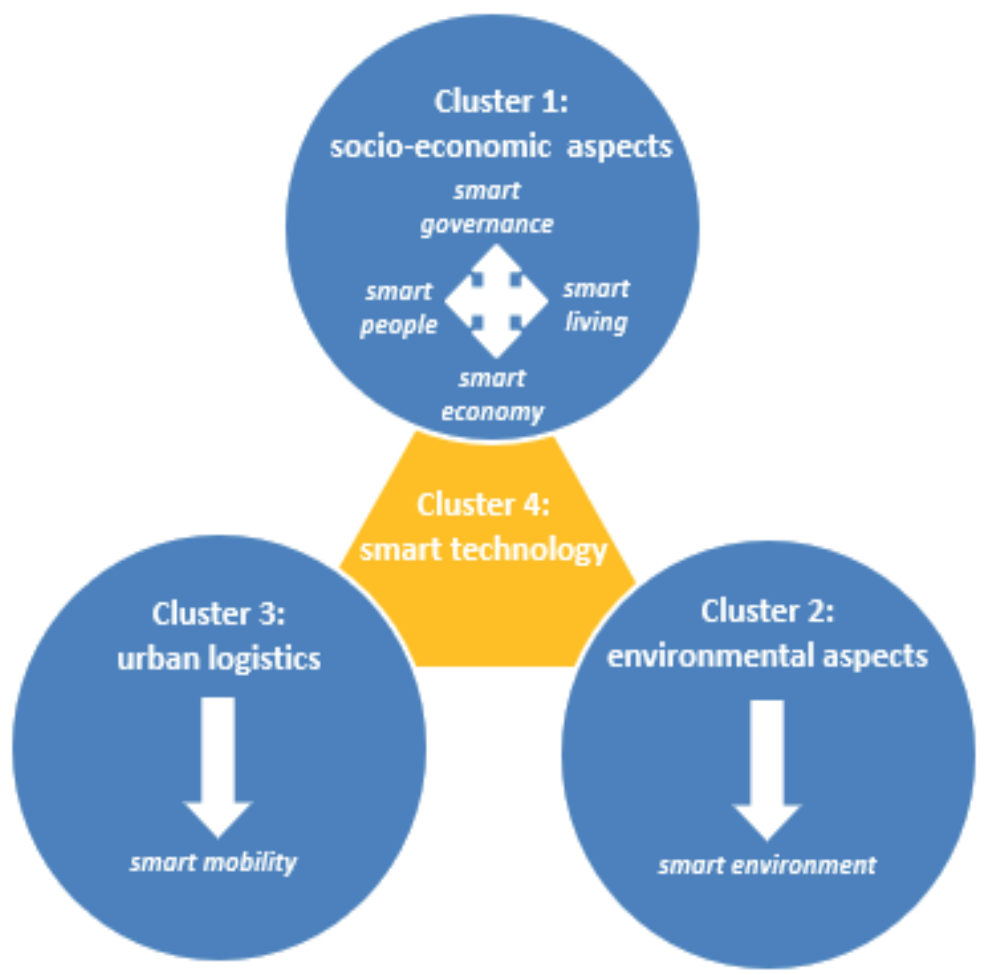

Fig. 8. Identified subareas related to smart city elements

mental aspects. A city cannot be named smart if it has no activities in the field of environmental protection and resource management methods. The care for the quality of the natural environment is of utmost importance, for example, by reducing emissions, pollution and using renewable energy sources. Generally, the principles of sustainable development should be followed. Analysing the third cluster, it can be noticed that the subject of urban logistics plays an important role in the smart city concept. In this context, urban logistics should primarily focus on planning, coordination and controlling processes related to a city or urban agglomeration, moving people and goods in a way that optimises costs, minimises congestion and improves the quality of life of the residents. The analysis of individual clusters revealed that the identified sub-areas could be related to the key elements required for a city to be called smart (Fig. 8).

Cluster 4- smart technology - refers to a set of advanced technologies used in cities, such as wireless sensor networks, IOT, big data, cloud computing, artificial intelligence, applications, systems, mobile devices, mobile applications, wireless smartphones. The smart technology refers to each of the smart city elements. However, based on conclusions learned from the literature review and the previous difficulties in implementing the smart city concept, the real needs of people should always be placed first, and all aspects of its surroundings should be considered. The smart technology is not in the centre but is a specific background for other elements. It is a tool for achieving goals, not an end in itself. Each of the elements of the smart city concept is a wide field of research. However, it should be remembered that they constitute one integral and inseparable whole, and they should be treated as such in the practical context. For a city to be described as smart, it must have all these elements.

\section{CONCLUSIONS}

A smart city is a relatively new concept. The dynamic development of innovative technologies provides opportunities to build smart cities. However, as demonstrated by the literature review, excessive focus on the technological aspect alone leads to many problems in the implementation of the smart city concept. A city can hardly become smart only by using technology. In the current perception of the "smart city" concept, there is a return to the needs and preferences of the inhabitants. They are the focus, and technical solutions are to serve their interests.

The bibliometric map created for this publication allowed identifying six sub-areas of research related to the smart city concept. While analysing the indi- 
vidual clusters, it was noticed that they fit into the necessary elements of the smart city concept. For a city to be really smart, it must integrate such elements as the smart economy, smart people, smart living, the smart environment, the smart governance and smart mobility.

The literature review identified a research gap, which shows that the implementation of the smart city concept is poorly embedded in a multi-sphere and multi-variant vision of the future In the opinion of the authors, a tool that would enable the development of a vision of the future of a smart city with the involvement of a wide range of stakeholders forming a local community, could be foresight, which has been successfully used in building a vision of the future of countries, regions and businesses (Nazarko, 2013; Nazarko et al. 2013, 2015a, 2015b; Ejdys, 2014; Szpilko 2015; Ejdys et al., 2019). It, therefore, seems appropriate to develop a foresight methodology for planning the future of smart cities, in which citizens are both users and co-creators of smart cities. To develop the methodology of creating smart city development based on foresight studies, research in this field of science will be continued by the authors.

\section{LITERATURE}

Aguilar, A. G., \& López, F. M. (2016). Espacios de pobreza en la periferia urbana y suburbios interiores de la Ciudad de México.Las desventajas acumuladas [Poverty spaces in the urban periphery and inner suburbs of the Mexico city accumulated disadvantages]. Eure, 42(125), 5-29. doi: 10.4067/ S0250-71612016000100001

Alam, S. S., Islam, A. J., Hasan, M. M., Rafid, M. N. M., Chakma, N., \& Imtiaz, M. N. (2018). Design and development of a low-cost IoT based environmental pollution monitoring system. 4th International Conference on Electrical Engineering and Information and Communication Technology, iCEEiCT,652-656.

Alchihabi, A., Dervis, A., Ever, E., \& Al-Turjman, F. (2019). A generic framework for optimizing performance metrics by tuning parameters of clustering protocols in WSNs. Wireless Networks, 25(3), 1031-1046. doi: 10.1007/s11276-018-1665-8

Alduais, N. A. M., Abdullah, I., \& Jamil, A. (2019). An efficient data collection algorithm for wearable / mobile tracking system in IoT /WSN. Electrical Power, Electronics, Communications, Controls and Informatics Seminar, EECCIS 2018, 250-254. doi: 10.1109/EECCIS.2018.8692815

Allam, Z., \& Dhunny, Z. A. (2019). On big data, artificial intelligence and smart cities. Cities, 89, 80-91. doi: 10.1016/j.cities.2019.01.032
Allwinkle, S., \& Cruickshank, P. (2011), Creating Smarter Cities: An Overview. Journal of Urban Technology, 18(2), 1-16. doi: 10.1080/10630732.2011.601103

Ameer, S., \& Shah, M. A. (2019). Exploiting big data analytics for smart urban planning. IEEE Vehicular Technology Conference, 2018-August. doi: 10.1109/ICSPCS.2018.8631726

Amritha, P. K., \& Kumar, P. P. A. (2019). Productive landscapes as a sustainable organic waste management option in urban areas. Environment, Development and Sustainability, 21(2), 709-726. doi: 10.1007/ s10668-017-0056-0

Azhdari, G., Lagzian, M., Shirazi, A., \& Fayyazi, M. (2019). Electronic human resource management adoption model in knowledge base small and medium enterprises. Iranian Journal of Information Processing Management, 34(2), 535-556. doi: 10.19166/derema. v13i1.491

Bashynska, I., \& Dyskina, A. (2018). The overview-analytical document of the international experience of building smart city. Business: Theory and Practice, 19, 228-241. doi: 10.3846/btp.2018.23

Bibri, S. E. (2019). On the sustainability of smart and smarter cities in the era of big data: An interdisciplinary and transdisciplinary literature review. Journal of Big Data, 6(1). doi: 10.1186/s40537-019-0182-7

Binti Adnan, S. N. N., Awang, J., Rahman, Z. A., Ibrahim, M., Long, A. S., Kamarzaman, H., \& Mohamed, S. B. (2018). The 'umran al 'alam theory's approach to the social smart city ethical. International Journal of Civil Engineering and Technology, 9(7), 269-277.

Bjørgen, A., Seter, H., Kristensen, T., \& Pitera, K. (2019). The potential for coordinated logistics planning at the local level: A Norwegian in-depth study of public and private stakeholders. Journal of Transport Geography, 76, 34-41. doi: 10.1016/j.jtrangeo.2019.02.010

Bugge, M. M., Fevolden, A. M., \& Klitkou, A. (2019). Governance for system optimization and system change: The case of urban waste. Research Policy, 48(4), 10761090. doi: 10.1016/j.respol.2018.10.013

Bui, K. N., \& Jung, J. J. (2019). Computational negotiationbased edge analytics for smart objects. Information Sciences, 480,222-236. doi: 10.1016/j.ins.2018.12.046

Cantas, M. R., Kavas, O., Tamilarasan, S., Gelbal, S. Y., \& Guvenc, L. (2019). Use of hardware in the loop (HIL) simulation for developing connected autonomous vehicle (CAV) applications. SAE Technical Papers, 2019-April. doi: 10.4271/2019-01-1063

Cao, W., Zhang, Y., \& Qian, P. (2019). The effect of innovation-driven strategy on green economic development in China-an empirical study of smart cities. International Journal of Environmental Research and Public Health, 16(9). doi: 10.3390/ ijerph16091520

Caparros-Midwood, D., Dawson, R., \& Barr, S. (2019). Low carbon, low risk, low density: Resolving choices about sustainable development in cities. Cities, 89, 252-267. doi: 10.1016/j.cities.2019.02.018

Caragliu, A., Del Bo, Ch., \& Nijkamp, P. (2011). Smart Cities in Europe. Journal of Urban Technology, 18(2), 6582. doi: 10.1080/10630732.2011.601117 
de Castro Pena, J. C., de Assis, J. C., da Silva, R. A., Honda, L. K., Pagani, M. I., \& Ribeiro, M. C. (2017). Beyond the mining pit: The academic role in social deliberation for participatory environmental planning. Perspectives in Ecology and Conservation, 15(3), 194-198. doi: 10.1016/j.pecon.2017.06.006

Carè, S., Trotta, A., Carè, R., \& Rizzello, A. (2018). Crowdfunding for the development of smart cities. Business Horizons, 61(4), 501-509. doi: 10.1016/j.bushor.2017.12.001

Certomà, C., \& Rizzi, F. (2017). Crowdsourcing processes for citizen-driven governance In $\mathrm{C}$. Certomà, $\mathrm{M}$. Dyer, L. Pocatilu, F. Rizzi (Eds.), Citizen Empowerment and Innovation in the Data-Rich City (pp. 5777). Cham, Switzerland: Springer Tracts in Civil Engineering. doi:10.1007/978-3-319-47904-0_4

Chakrabarty, A. (2019). Smart mischief: An attempt to demystify the smart cities craze in India. Environment and Urbanization, 31(1), 193-208. doi: 10.1177/0956247818769234

Chammas, M., Makhoul, A., \& Demerjian, J. (2019). An efficient data model for energy prediction using wireless sensors. Computers and Electrical Engineering, 76, 249-257. doi: 10.1016/j.compeleceng.2019.04.002

Chen, M. (2019). Modeling and simulation analysis of road network based on VISSIM. Proceedings - 2019 International Conference on Intelligent Transportation, Big Data and Smart City, ICITBS 2019, 32-35. doi: 10.1109/ICITBS.2019.00017

Chondrogiannis, E., Andronikou, V., Karanastasis, E., \& Varvarigou, T. (2019). A novel approach for clinical data harmonization. IEEE International Conference on Big Data and Smart Computing, BigComp 2019 Proceedings. doi: 10.1109/BIGCOMP.2019.8679239

Chong, M., Habib, A., Evangelopoulos, N., \& Park, H. W. (2018). Dynamic capabilities of a smart city: An innovative approach to discovering urban problems and solutions. Government Information Quarterly, 35(4), 682-692. doi: 10.1016/j.giq.2018.07.005

Chourabi, H., Nam, T., Walker, S., Gil-Garcı'a, J., Mellouli, S., Nahon, K., Pardo, T. A., \& Scholl, H. (2012). Understanding Smart Cities: An Integrative Framework. Proceedings of 45 th Hawaii International Conference on Systems Science, 2289-2297.

Cleophas, C., Cottrill, C., Ehmke, J. F., \& Tierney, K. (2019). Collaborative urban transportation: Recent advances in theory and practice. European Journal of Operational Research, 273(3), 801-816. doi: 10.1016/j.ejor.2018.04.037

Deng, J. (2019). The teaching reform of higher vocational business English course informationization on the background of education informationization 2.0. Proceedings - 2019 International Conference on Intelligent Transportation, Big Data and Smart City, ICITBS 2019, 324-326. doi: 10.1109/ICITBS.2019.00085

Dlamini, S., Simatele, M. D., \& Serge Kubanza, N. (2019). Municipal solid waste management in South Africa: From waste to energy recovery through waste-to-energy technologies in Johannesburg. Local Environment, 24(3), pp. 249-257. doi: 10.1080/13549839.2018.1561656
Dobrzyński, M., Dziekoński, K., \& Jurczuk, A. (2013). Analiza bibliometryczna artykułów w "Gospodarce Materiałowej i Logistyce" z lat 2010-2012 [Bibliometric analysis of articles in "Materials Management and Logistics" from the years 2010-2012]. Gospodarka Materiałowa i Logistyka, 12, 24-31.

Dohler, M., Vilajosana, I., Vilajosana, X., \& Llosa, J. (2011). Smart Cities: An action plan. Proceedings of Barcelona Smart Cities Congress, Spain, Barcelona, 1-6.

van Eck, N.J., \& Waltman, L. (2011). VOSviewer Manual. Manual for VOSviewer version 1.3.0. software documentation.

Ejdys, J. (2014). Future oriented strategy for SMEs. Procedia - Social and Behavioral Sciences, 156, 8-12. doi: 10.1016/j.sbspro.2014.11.110

Ejdys, J., Gudanowska, A., Halicka, K., Kononiuk, A., Magruk, A., Nazarko, J., Nazarko, L., Szpilko, D., \& Widelska, U. (2019). Foresight in higher education institutions: evidence from Poland. Foresight and STI Governance, 13(1), 77-89. doi: 10.17323/25002597.2019.1.77.89

Elzen, B., Geels, F. W., \& Green, K. (2004). Transitions to sustainability: lessons learned and remaining challenges. In B. Elzen, F. W. Geels, \& K. Green (Eds.), System Innovation and the Transition to Sustainability, (pp. 282-300). United Kingdom, Cheltenham: Edward Elgar Publishing.

Fang C. C., \& Lai, C. (2018). Application for the geriatrics in cognitive city: Prevention of lost patient with dementia. Proceedings - 2018 1st International Cognitive Cities Conference, IC3, 28-31.

Faramehr, S., Hemida, H., \& Fujiyama, T. (2019). Evaluation of the impact of urban water systems on railways: The scenario of track flooding caused by a water main burst. Proceedings of the Institution of Mechanical Engineers, Part F: Journal of Rail and Rapid Transit. doi: 10.1177/0954409719830184

Fernández Vilas, A., Díaz Redondo, R. P., \& Ben Khalifa, M. (2019). Analysis of crowds' movement using Twitter. Computational Intelligence, 35(2), pp. 448472. doi: 10.1111/coin.12205

Fernandez-Guell, J. M., Guzmán-Arana, S., Collado-Lara, M., \& Fernandez-Anez, V. (2016). How to Incorporate Urban Complexity, Diversity and Intelligence into Smart Cities Initiatives. Smart Cities: First International Conference, Smart-CT 2016, Málaga, Spain, June 15-17, 85-94.

Ferrer, J., López-Ibáñez, M., \& Alba, E. (2019). Reliable simulation-optimization of traffic lights in a realworld city. Applied Soft Computing Journal, 78, 697711. doi: 10.1016/j.asoc.2019.03.016

Fietkiewicz, K. J., Mainka, A., \& Stock, W. G. (2017). eGovernment in cities of the knowledge society. An empirical investigation of Smart Cities' governmental websites. Government Information Quarterly, 34(1), 75-83. doi: /10.1016/j.giq.2016.08.003

Firdausiyah, N., Taniguchi, E., \& Qureshi, A. G. (2019). Modeling city logistics using adaptive dynamic programming based multi-agent simulation. Transportation Research Part E: Logistics and Transportation Review, 125, 74-96. doi: 10.1016/j. tre.2019.02.011 
Garg, S., Singh, A., Kaur, K., Aujla, G. S., Batra, S., Kumar, N., \& Obaidat, M. S. (2019). Edge computingbased security framework for big data analytics in VANETs. IEEE Network, 33(2), 72-81. doi: 10.1109/ MNET.2019.1800239

Gil-Garcia, J. R., Pardo, T. A., Nam T. (2015). A Comprehensive View of the 21st Century City: Smartness as Technologies and Innovation in Urban Contexts. In Gil-Garcia, J. R., Pardo, T., \& Nam T. (Eds.), Smarter as the New Urban Agenda. Public Administration and Information Technology (pp. 1-19). Cham, Switzerland: Springer.

Godoi, F. N., Denardin, G. W., \& Barriquello, C. H. (2019). Reliability enhancement of packet delivery in multi-hop wireless sensor network. Computer Networks, 153, 86-91. doi: 10.1016/j.comnet.2019.02.013

Gonzaga, E. (2019). Precarious nostalgia in the tropical smart city: Transmedia memory, urban informatics, and the singapore golden jubilee. Cultural Studies, 33(1), 147-169. doi: 10.1080/09502386.2018.1428644

Greenfield, E. A. (2018). Age-friendly initiatives, social inequalities, and spatial justice. Hastings Center Report, 48, 41-45. doi: 10.1002/hast.912

Grimaldi, D., Fernandez, V., \& Carrasco, C. (2019). Heuristic for the localization of new shops based on business and social criteria. Technological Forecasting and Social Change, 142, 249-257. doi: 10.1016/ j.techfore.2018.07.034

Gudanowska, A. E. (2015). Tworzenie mapy wiedzy opartej na tematyce projektów badawczo - rozwojowych na przykładzie województwa podlaskiego [Creating knowledge maps based on the themes of $\mathrm{R} \& \mathrm{D}$ projects on the example of the Podlaskie region]. Economics and Management, 7(1), 257-270. doi: 10.12846/j.em.2015.01.16

Gudanowska, A. E. (2017). A map of current research trends within technology management in the light of selected literature. Management and Production Engineering Review, 8(1), 78-88. doi: 10.1515/ mper2017-0009

Guo, J., Ma, J., Li, X., Zhang, J., \& Zhang, T. (2017). An attribute-based trust negotiation protocol for D2D communication in smart city balancing trust and privacy. Journal of Information Science and Engineering, 33(4), 1007-1023. doi: 10.6688/JISE.2017.33.4.10

Halicka, K. (2017). Main concepts of technology analysis in the light of the literature on the subject. Procedia Engineering, 182, 291-298, doi: 10.1016/j.proeng.2017.03.196

Halmy, M. W. A. (2019). Assessing the impact of anthropogenic activities on the ecological quality of arid mediterranean ecosystems (case study from the northwestern coast of Egypt). Ecological Indicators, 101, 992-1003. doi: 10.1016/j.ecolind.2019.02.005

Heaton, J., \& Parlikad, A. K. (2019). A conceptual framework for the alignment of infrastructure assets to citizen requirements within a smart cities framework. Cities, 90, 32-41. doi: 10.1016/j. cities.2019.01.041 van Holm, E. J. (2019). Unequal cities, unequal participation: The effect of income inequality on civic engagement. American Review of Public Administration, 49(2), 135-144. doi: 10.1177/0275074018791217

Horgan, D., \& Dimitrijević, B. (2019). Frameworks for citizens participation in planning: From conversational to smart tools. Sustainable Cities and Society, 48. doi:10.1016/j.scs.2019.101550

Hu, S., \& Jiang, T. (2019). Artificial intelligence technology challenges patent laws. Proceedings - 2019 International Conference on Intelligent Transportation, Big Data and Smart City, ICITBS 2019, 241-244. doi: 10.1109/ICITBS.2019.00064

Huang, H., Lu, Z., Peng, R., Feng, Z., Xuan, X., Hung, P. C. K., \& Huang, S. C. (2019). Efficiently querying large process model repositories in smart city cloud workflow systems based on quantitative ordering relations. Information Sciences, 495, 100-115. doi: 10.1016/j.ins.2019.04.058

Huang, K., Zhang, X. S., \& Wang, X. F. (2017), Block-level message-locked encryption with polynomial commitment for IoT data. Journal of Information Science and Engineering, 33(4), 891-905. doi: 10.6688/ JISE.2017.33.4.2

Indrawati I., Azkalhaq, N., \& Amani, H. (2018). Indicators to measure smart economy: An Indonesian perspective. ACM International Conference Proceeding Series, 173-179. doi: 10.1145/3278252.3278278

Ismagilova, E., Hughes, L., Dwivedi, Y. K., \& Raman, K. R. (2019). Smart cities: Advances in research - An information systems perspective. International Journal of Information Management, 47, 88-100. doi: 10.1016/j. ijinfomgt.2019.01.004

Jan, M. A., Zhang, W., Usman, M., Tan, Z., Khan, F., \& Luo, E. (2019). SmartEdge: An end-toend encryption framework for an edge-enabled smart city application. Journal of Network and Computer Applications, 137, 1-10. doi: 10.1016/j. jnca.2019.02.023

Jarocka, M., \& Wang, H. (2018). Definition and classification criteria of logistics services for elderly. Engineering Management in Production and Services, 10(4), 65-75. doi: 10.2478/emj-2018-0023

Jayantha, W. M., Qian, Q. K., \& Yi, C. O. (2018). Applicability of 'Aging in place' in redeveloped public rental housing estates in hong kong. Cities, 83, 140-151. doi: 10.1016/j.cities.2018.06.016

Ji, W., Xu, J., Qiao, H., Zhou, M., \& Liang, B. (2019). Visual IoT: Enabling internet of things visualization in smart cities. IEEE Network, 33(2), 102-110. doi: 10.1109/MNET.2019.1800258

Julian, V., \& Botti, V. (2019). Multi-agent systems. Applied Sciences, 9(7). doi: 10.3390/app9071402

Juwet, G., \& Ryckewaert, M. (2018). Energy transition in the nebular city: Connecting transition thinking, metabolism studies, and urban design. Sustainability, 10(4). doi: 10.3390/su10040955

Kamel Boulos, M. N., Peng, G., \& Vopham, T. (2019). An overview of GeoAI applications in health and healthcare. International Journal of Health Geographics, $18(1)$. 
Khadse, V., Mahalle, P. N., \& Biraris, S. V. (2019). An empirical comparison of supervised machine learning algorithms for internet of things data. Proceedings - 2018 4th International Conference on Computing, Communication Control and Automation, ICCUBEA 2018. doi: 10.1109/ICCUBEA.2018.8697476

Kong, X., Li, M., Li, J., Tian, K., Hu, X., \& Xia, F. (2019). CoPFun: An urban co-occurrence pattern mining scheme based on regional function discovery. World Wide Web, 22(3), 1029-1054. doi: 10.1007/s11280018-0578-x

Kosheleva, N. E., Vlasov, D. V., Korlyakov, I. D., \& Kasimov, N. S. (2018). Contamination of urban soils with heavy metals in Moscow as affected by building development. Science of the Total Environment, 636, 854-863. doi: 10.1016/j.scitotenv.2018.04.308

Kovács, Z., Farkas, Z. J., Egedy, T., Kondor, A. C., Szabó, B., Lennert, J., Baka D., \& Kohán, B. (2019). Urban sprawl and land conversion in post-socialist cities: The case of metropolitan Budapest. Cities, 92, 71-81. doi: 10.1016/j.cities.2019.03.018

Krämer, M., Frese, S., \& Kuijper, A. (2019). Implementing secure applications in smart city clouds using microservices. Future Generation Computer Systems, 99, 308-320. doi: 10.1016/j.future.2019.04.042

Kuang, A., Zhang, S., \& Yang, H. (2019). Research on signal control method of isolated intersection based on the queuing length reliability. Proceedings - 2019 International Conference on Intelligent Transportation, Big Data and Smart City, ICITBS 2019, 533-535. doi: 10.1109/ICITBS.2019.00133

Kumar, S., Lal, N., \& Chaurasiya, V. K. (2019). An energy efficient IPv6 packet delivery scheme for industrial IoT over G.9959 protocol based wireless sensor network (WSN). Computer Networks, 154, 79-87. doi: 10.1016/j.comnet.2019.03.001

Kundu, D. (2019). Blockchain and trust in a smart city. Environment and Urbanization ASIA, 10(1), 3143. doi: $10.1177 / 0975425319832392$

Lakshmanaprabu, S. K., Shankar, K., Sheeba Rani, S., Abdulhay, E., Arunkumar, N., Ramirez, G., \& Uthayakumar, J. (2019). An effect of big data technology with ant colony optimization-based routing in vehicular ad hoc networks: Towards smart cities. Journal of Cleaner Production, 217, 584-593. doi: 10.1016/j. jclepro.2019.01.115

Lanjouw, P., \& Marra, M. R. (2018). Urban poverty across the spectrum of Vietnam's towns and cities. World Development, 110, 295-306. doi: 10.1016/j.worlddev.2018.06.011

Lee, J. H., Hancock, M. G., \& Hu, M.-Ch. (2014). Towards an effective framework for building smart cities: Lessons from Seoul and San Francisco. Technological Forecasting \& Social Change, 89, 80-99. doi: 10.1016/j.techfore.2013.08.033

Li, L. (2019). Evaluation model of education service quality satisfaction in colleges and universities dependent on classification attribute big data feature selection algorithm. Proceedings - 2019 International Conference on Intelligent Transportation, Big Data and Smart City, ICITBS 2019, 645-649. doi: 10.1109/IC-
ITBS.2019.00160

Li, X., Zhu, S., Gelbal, S. Y., Cantas, M. R., Aksun Guvenc, B., \& Guvenc, L. (2019). A unified, scalable and replicable approach to development, implementation and HIL evaluation of autonomous shuttles for use in a smart city. SAE Technical Papers, 2019-April. doi: 10.4271/2019-01-0493

Lombardi, P., Giordano, S., Farouh, H., \& Yousef, W. (2012). Modelling the Smart City Performance. Innovation: The European Journal of Social Science Research, 25(2), 137-149. doi: 10.1080/13511610.2012.660325

Luo, Y., Du, X., \& Sun, Y. (2019). Survey on real-time anomaly detection technology for big data streams. Proceedings of the International Conference on Anti-Counterfeiting, Security and Identification, ASID, 2018-November, 26-30. doi: 10.1109/ICASID.2018.8693216

de M. Del Esposte, A., Santana, E. F. Z., Kanashiro, L., Costa, F. M., Braghetto, K. R., Lago, N., \& Kon, F. (2019). Design and evaluation of a scalable smart city software platform with large-scale simulations. Future Generation Computer Systems, 93, 427-441. doi: 10.1016/j.future.2018.10.026

Ma, B., Li, H., Wei, Y. D., Xue, D., \& Jiang, J. (2018). Spatial structure and mechanism of urban poverty in Xi'an city. Acta Geographica Sinica, 73(6), 1018-1032. doi: $10.11821 / \mathrm{dl} x \mathrm{~b} 201806003$

Ma, R., \& Lam, P. T. I. (2019). Investigating the barriers faced by stakeholders in open data development: A study on Hong Kong as a "smart city". Cities, 92, 36-46. doi: 10.1016/j.cities.2019.03.009

Mahmoud, H., \& Divigalpitiya, P. (2019). Spatiotemporal variation analysis of urban land expansion in the establishment of new communities in Upper Egypt: A case study of New Asyut city. Egyptian Journal of Remote Sensing and Space Science, 22(1), 59-66. doi: 10.1016/j.ejrs.2018.03.006

Manchester, H., \& Cope, G. (2019). Learning to be a smart citizen. Oxford Review of Education, 45(2), 224241. doi: 10.1080/03054985.2018.1552582

Mannan, S., \& Callenes-Sloan, J. (2019). Treety: A datadriven approach to urban canopy development. IEEE International Smart Cities Conference, ISC2 2018. doi:10.1109/ISC2.2018.8656956

Manville, C., Cochrane, G., Cave, J., Millard, J., Pederson, J. K., Thaarup, R. K., Liebe, A., Wissner, M., Massink, R., \& Kotterink, B. (2014). Mapping Smart Cities in the EU. Study. Directorate-General for Internal Policies, Policy Department A: Economic and Scientific Policy, European Parliament, Brussels.

Marcuzzi, F., \& Tonello, A. M. (2019). Artificial-intelligence-based performance enhancement of the G3PLC LOADng routing protocol for sensor networks. Proceedings of the 2019 IEEE International Symposium on Power Line Communications and its Applications, ISPLC 2019, 114-119. doi: 10.1109/ ISPLC. 2019.8693390

Marrero, D., Macías, E., Suárez, Á., Santana, J. A., \& Mena, V. (2019). Energy saving in smart city wireless backbone network for environment sensors. Mobile 
Networks and Applications, 24(2), 700-711. doi: 10.1007/s11036-016-0786-5

Mattoni, B., Gugliermetti, F., Bisegna, F. (2015). A multilevel method to assess and design the renovation and integration of Smart Cities. Sustainable Cities and Society, 15, 105-119. doi: 10.1016/j. scs.2014.12.002

Mattos, D. M. F., Velloso, P. B., \& Duarte, O. C. M. B. (2019). An agile and effective network function virtualization infrastructure for the internet of things. Journal of Internet Services and Applications, 10(6). doi: 10.1186/s13174-019-0106-y

Matyja, R. (2017). Miasto jako przestrzeń, węzeł i system. Analiza z perspektywy badań politologicznych [The city as space, node and system. Analysis from the perspective of political science research]. Acta Politica Polonica, 3(41), 5-16. doi: 10.18276/ap.2017.41-01

Mavrodieva, A. V., Daramita, R. I. F., Arsono, A. Y., Yawen, L., \& Shaw, R. (2019). Role of civil society in sustainable urban renewal (Machizukuri) after the Kobe Earthquake. Sustainability, 11(2). 10.3390/ su11020335

Mesjasz-Lech, A. (2014), Development of public transport in the city a challenge for urban logistics in terms of sustainable development. Forum Scientiae Oeconomia 2(4), 63-75.

Min-Allah, N., Qureshi, M. B., Alrashed, S., \& Rana, O. F. (2019). Cost efficient resource allocation for realtime tasks in embedded systems. Sustainable Cities and Society, 48. doi: 10.1016/j.scs.2019.101523

Mishra, A. K. (2019). Henry George and Mohring-Harwitz theorems: Lessons for financing smart cities in developing countries. Environment and Urbanization ASIA, 10(1), 13-30. doi: 10.1177/0975425318821797

Mizielińska-Chmielewska, M. (2018). Inteligentne miasta podążają za modelem ekonomii współdzielenia [Smart Cities follow the sharing economy model]. Retrieved from http://www.inteligentnemiasto.com/ smart-cities/inteligentne-miasta-podazaja-za-modelem-ekonomii-wspoldzielenia

Molpeceres Arnáiz, S. [2017]. Smart City vs. Wise City. En torno a la ciudad y las nuevas tecnologías el caso de Barcelona [Smart City vs. Wise City. Around the city and new technologies the the case of Barcelona]. Cultura, Lenguaje y Representación, 17, 129-155. doi: 10.6035/clr.2017.17.9

Mone, G. (2015). The new smart cities. Communications of the ACM, 58(7), 20-21. doi: 10.1145/2771297

Morgado, L., Rodrigues, R., Coelho, A., Magano, O., Calçada, T., Cunha, P. T., \& Ramos, L. (2015). Cities in citizens' hands. Procedia Computer Science, 67, 430-438. doi: 10.1016/j.procs.2015.09.288

Muktiali, M. (2018). Policy analysis of poverty alleviation in Semarang city using spatial and sectoral approach. IOP Conference Series: Earth and Environmental Science, 123(1). doi: 10.1088/1755-1315/123/1/012046

Munoz-Pandiella, I., Bosch, C., Merillou, N., Patow, G., Merillou, S., \& Pueyo, X. (2018). Urban weathering: Interactive rendering of polluted cities. IEEE Transactions on Visualization and Computer
Graphics, 24(12), 3239-3252. doi: 10.1109/ TVCG.2018.2794526

Nam, T., \& Pardo, T. A. (2014). The changing face of a city government: A case study of Philly311. Government Information Quarterly, 31(Supplement 1), S1-S9. doi: 10.1016/j.giq.2014.01.002

Naphade, M., Banavar, G., Harrison, C., Paraszczak, J., \& Morris, R. (2011). Smarter Cities and Their Innovation Challenges. Computer, 44(6), 32-39. doi: 10.1109/MC.2011.187

Nataraj, S., Ferone, D., Quintero-Araujo, C., Juan, A. A., \& Festa, P. (2019). Consolidation centers in city logistics: A cooperative approach based on the location routing problem. International Journal of Industrial Engineering Computations, 10(3), 393-404. doi: 10.5267/j.ijiec.2019.1.001

Nazarko, J. (2013). Regionalny Foresight Gospodarczy. Metodologia $i$ instrumentarium badawcze [Regional Economic Foresight. Methodology and Research Tools]. Warsaw, Poland: Związek Pracodawców Warszawy i Mazowsza.

Nazarko, J., Ejdys, J., Halicka, K., \& Nazarko, Ł. (2015a). Foresight Application for Transport Sector. In Fiorini, M. (Ed.) Clean Mobility and Intelligent Transport Systems (pp. 379-402). London, United Kingdom: The Institution of Engineering and Technology.

Nazarko, J., Glinska, U., Kononiuk, A., Nazarko, L. (2013). Sectoral foresight in Poland: thematic and methodological analysis. International Journal of Foresight and Innovation Policy, 9(1), 19-38. doi: 10.1504/IJFIP.2013.051759

Nazarko, J., Radziszewski, P., Dębkowska, K., Ejdys, J., Gudanowska, A., Halicka, K., Kilon, J., Kononiuk, A., Kowalski, K., Krol, J., Nazarko, Ł., Sarnowski, M., \& Vilutiene, T. (2015b). Foresight Study of Road Pavement Technologies. Procedia Engineering, 122, 129-136. doi: 10.1016/j.proeng.2015.10.016

Neuroni, A. C., Haller, S., van Winden, W., Carabias-Hütter, V., \& Yildirim, O. (2019). Public value creation in a smart city context: An analysis framework. In M. P. Rodriguez Bolivar (Ed.), Setting Foundations for the Creation of Public Value in Smart Cities (pp. 49-76). Cham, Switzerland: Springer Nature AG. doi:10.1007/978-3-319-98953-2_3

Novo Vázquez, A., \& Vicente, M. R. (2019). Exploring the determinants of e-participation in smart cities. In A. Novo Vázquez, \& M. R. Vicente, E-Participation in Smart Cities: Technologies and Models of Governance for Citizen Engagement (pp. 157-178). Cham, Switzerland: Springer International Publishing AG.d oi:10.1007/978-3-319-89474-4_8

Noworól, A. (2011), Zarządzanie miastem - podstawy teoretyczne [Urban management - theoretical basis]. In B. Kożuch, C. Kochalski (Eds.), Strategiczne zarzadzanie miastem $w$ teorii i praktyce urzędu miasta Poznania [Strategic management of the city in the theory and practice of the Poznan City Hall], (pp. 2541). Kraków, Poland: Monografie i Studia Instytutu Spraw Publicznych Uniwersytetu Jagiellońskiego 7.

Oliveira, Á., \& Santos, I. (2018). Human smart cities. Cocreation methodologies and technologies. WMSCI 
2018 - 22nd World Multi-Conference on Systemics, Cybernetics and Informatics, Proceedings, 1, 154-160.

Onoda, Y. (2018). A paradigm shift in city management practices targets the sustainable society. NEC Technical Journal, 13(1), 19-23.

Ortiz-Fournier, L. V., Márquez, E., Flores, F. R., RiveraVázquez, J. C., \& Colon, P. A. (2010). Integrating educational institutions to produce intellectual capital for sustainability in Caguas, Puerto Rico. Knowledge Management Research and Practice, 8(3), 203-215. doi: 10.1057/kmrp.2010.11

Panchanathan, S., Mcdaniel, T., Tadayon, R., Rukkila, A., \& Venkateswara, H. (2019). Smart stadia as testbeds for smart cities: Enriching fan experiences and improving accessibility. International Conference on Computing, Networking and Communications, ICNC 2019, 542-546.

Panchanathan, S., Mcdaniel, T., Tadayon, R., Rukkila, A., \& Venkateswara, H. (2019). Smart stadia as testbeds for smart cities: Enriching fan experiences and improving accessibility. International Conference on Computing, Networking and Communications, ICNC 2019, 542-546. doi: 10.1109/ICCNC.2019.8685580

Peng, G. C. A., Nunes, M. B., \& Zheng, L. (2017). Impacts of low citizen awareness and usage in smart city services: The case of London's smart parking system. Information Systems and e-Business Management, 15(4), 845-876. doi: 10.1007/s10257-016-0333-8

Perboli, G., De Marco, A., Perfetti, F., \& Marone, M. (2014). A new Taxonomy of Smart City Projects. Transportation Research Procedia, 3, 470-478. 10.1016/j. trpro.2014.10.028

Perng, S., Kitchin, R., \& Mac Donncha, D. (2018). Hackathons, entrepreneurial life and the making of smart cities. Geoforum, 97, 189-197. doi: 10.1016/j.geoforum.2018.08.024

Petrova, S., \& Prodromidou, A. (2019). Everyday politics of austerity: Infrastructure and vulnerability in times of crisis. Environment and Planning C: Politics and Space. doi: doi.org/10.1177/2399654419831293

Pham, T. T., \& Phan, C. T. (2018). Risk management: Awareness, identification and mitigation in public private partnerships of technical infrastructure projects in da nang. Proceedings 2018 4th International Conference on Green Technology and Sustainable Development, GTSD, 18-23.

Proseedmag (2017). Smart city - wady i zalety [Smart city - advantages and disadvantages]. Retrieved from https://proseedmag.pl/gospodarka/smart-citywady-zalety

Putra, H. Y., Putra, H., \& Kurniawan, N. B. (2019). Big data analytics algorithm, data type and tools in smart city: A systematic literature review. International Conference on Information Technology Systems and Innovation, ICITSI 2018 - Proceedings, 474-478. doi: 10.1109/ICITSI.2018.8696051

Rath, M., \& Pattanayak, B. (2019). Technological improvement in modern health care applications using internet of things (IoT) and proposal of novel health care approach. International Journal of Human Rights in Healthcare, 12(2), 148-162. doi: 10.1108/
IJHRH-01-2018-0007

Ravetz, J. (2017). From 'smart' cities to 'wise': synergistic pathways for collective urban intelligence. JPI Urban Europe - Urban Transitions Pathways Symposium. Retrieved from https://jpi-urbaneurope.eu/app/uploads/ 2017/04/Ravetz_From-smart-to-wise.pdf

Reddy, D. V. S., \& Mehta, R. V. K. (2019). Smart traffic management system for smart cities using reinforcement learning algorithm. International Journal of Recent Technology and Engineering, 7(6), 12-15.

Sadeghpour, S., Jaseemuddin, M., \& Kharbish, S. (2019). Cluster-based cache placement in 5G network. Proceedings - 20th International Conference on High Performance Computing and Communications, 16th International Conference on Smart City and 4th International Conference on Data Science and Systems, HPCC/SmartCity/DSS 2018, 457-465. doi: 10.1109/HPCC/SmartCity/DSS.2018.00091

Safiullin, A., Krasnyuk, L., \& Kapelyuk, Z. (2019). Integration of industry 4.0 technologies for "smart cities" development. IOP Conference Series: Materials Science and Engineering, 497(1).

Schaffers, H., Ratti, C., \& Komninos, N. (2012). Special issue on smart applications for smart cities - new approaches to innovation: Guest editors' introduction. Journal of Theoretical and Applied Electronic Commerce Research, 7(3), 2-5. doi: 10.4067/S071818762012000300005

Schmitt, S., Kandah, F. I., \& Brownell, D. (2019). Intelligent threat hunting in software-defined networking. IEEE International Conference on Consumer Electronics, ICCE 2019. doi: 10.1109/ICCE.2019.8661952

Scorţar, L. M., Vereş Vincenţiu, M. M., \& Anamaria, M. (2010). Solid waste disposal problems in Arieș urban community from Cluj county. Polish Journal of Management Studies, 2(2), 116-123.

Sedighian Kashi, S. (2019). Area coverage of heterogeneous wireless sensor networks in support of internet of things demands. Computing, 101(4), 363-385. doi: 10.1007/s00607-018-0623-8

Sharma, G., \& Kalra, S. (2019). Advanced multi-factor user authentication scheme for E-governance applications in smart cities. International Journal of Computers and Applications, 41(4), 312-327. doi: 10.1080/1206212X.2018.1445352

Shin, D. H. (2009). Ubiquitous city: Urban technologies, urban infrastructure and urban informatics. Journal of Information Science, 35(5), 515-526. doi: $10.1177 / 0165551509100832$

Siderska, J., \& Jadaa K. S. (2018). Cloud manufacturing: a service-oriented manufacturing paradigm. A review paper, Engineering Management in Production and Services, 10(1), 22-31. doi: 10.1515/emj-20180002

Sikora-Fernandez, D. (2017). Smart cities $w$ Polsce to nadal utopia [Smart cities in Poland are still a utopia]. Retrieved from http://urbnews.pl/smart-cities-polscenadal-utopia/

Sittón-Candanedo, I., Alonso, R. S., Corchado, J. M., Rodríguez-González, S., \& Casado-Vara, R. (2019). A review of edge computing reference architectures 
and a new global edge proposal. Future Generation Computer Systems, 99, 278-294. doi: 10.1016/j.future.2019.04.016

Sittón-Candanedo, I., Alonso, R. S., Corchado, J. M., Rodríguez-González, S., \& Casado-Vara, R. (2019). A review of edge computing reference architectures and a new global edge proposal. Future Generation Computer Systems, 99, 278-294. doi: 10.1016/j.future.2019.04.016

Sodiq, A., Baloch, A. A. B., Khan, S. A., Sezer, N., Mahmoud, S., Jama, M., \& Abdelaal, A. (2019). Towards modern sustainable cities: Review of sustainability principles and trends. Journal of Cleaner Production, 227, 972-1001. doi: 10.1016/j.jclepro.2019.04.106

Sou, G. (2019). Household self-blame for disasters: Responsibilisation and (un)accountability in decentralised participatory risk governance. Disasters, 43(2), 289310. doi: 10.1111/disa.12319

Sproull, L., \& Patterson, J. F. (2004). Making information cities livable. Communications of the ACM, 47(2), 3337. doi: 10.1145/966389.966412

Stawasz, D., \& Sikora-Fernandez, D. (2015). Zarzadzanie $w$ polskich miastach zgodnie $z$ koncepcja smart city [Management in Polish cities according to the smart city concept]. Warsaw, Poland: Placet.

Stawasz, D., \& Sikora-Fernandez, D. (2016). Koncepcja smart city na tle procesów i uwarunkowań rozwoju współczesnych miast [The smart city concept against the background of processes and conditions for the development of modern cities]. Łódź, Poland: Wydawnictwo Uniwersytetu Łodzkiego.

Stolfi, F., \& Sussman, G. (2001). Telecommunications and transnationalism: the polarization of social space. Information Society, 17(1), 49-62. doi: $10.1080 / 019722401750067423$

Streitz, N. (2017). Re-defining the "smart everything" paradigm: Towards reconciling humans and technology. Proceedings of the International Conference on ICT, Society and Human Beings 2017 - Part of the Multi Conference on Computer Science and Information Systems 2017.

Szołtysek, J., \& Otręba, R. (2015). Zarządzanie miastem i jego wpływ na jakość życia mieszkańców miast województwa śląskiego - doniesienie badawcze [City management and its influence on the quality of life of city dwellers of the Silesian Voivodeship - research report]. Problemy Rozwoju Miast, Kwartalnik Naukowy Instytutu Rozwoju Miast, 12(2), 37-42.

Szpilko, D. (2015). The Future of Tourism Development in the Podlaskie Voivodeship. Procedia - Social and Behavioral Sciences, 213, 977-984. doi: 10.1016/j.sbspro.2015.11.514

Szpilko, D. (2017). Tourism Supply Chain - overview of selected literature. Procedia Engineering, 182, 687-693, doi: 10.1016/j.proeng.2017.03.180

Tan, M. (1999). Creating the digital economy: strategies and perspectives from Singapore. International Journal of Electronic Commerce, 3(3), 105-122.

Targowski, A. S. (1990). Strategies and architecture of the electronic global village. Information Society, 17(3), 187-202. doi: 10.1080/01972243.1990.9960094

Tay, K. -. K. C., Supangkat, S. H., Cornelius, G., \& Arman, A. A. (2018). The SMART initiative and the Garuda smart city framework for the development of smart cities. Proceeding - 2018 International Conference on ICT for Smart Society: Innovation Toward Smart Society and Society 5.0, ICISS 2018. doi: 10.1109/ ICTSS.2018.8549961

Tenney, M., Hall, G. B., \& Sieber, R. E. (2019). Use the below title: A crowd sensing system identifying geotopics and community interests from user-generated content. International Journal of Geographical Information Science. doi:10.1080/13658816.2019.15 91413

Timmerman, R., Marshall, S., \& Zhang, Y. (2019). Towards socially sustainable urban design: Analysing acto Rarea relations linking micro-morphology and microdemocracy. International Journal of Sustainable Development and Planning, 14(1), 20-30. doi: 10.2495/SDP-V14-N1-20-30

Tomaszewska E. J., \& Florea, A. (2018). Urban smart mobility in the scientific literature - bibliometric analysis. Engineering Management in Production and Services, 10(2), 41-56. doi: 10.2478/emj-2018-0010

Trencher, G. (2019). Towards the smart city 2.0: Empirical evidence of using smartness as a tool for tackling social challenges. Technological Forecasting and Social Change, 142, 117-128. doi: 10.1016/j.techfore.2018.07.033

United Nations, Department of Economic and Social Affairs (2018). World Urbanization Prospects 2018: Key Facts, New York.

Vaidya, B., \& Mouftah, H. T. (2019). Automated reservation mechanism for charging connected and autonomous EVs in smart cities. IEEE Vehicular Technology Conference, 2018-August. doi: 10.1109/ VTCFall.2018.8690905

Vhaduri, S., Poellabauer, C., Striegel, A., Lizardo, O., \& Hachen, D. (2018). Discovering places of interest using sensor data from smartphones and wearables. IEEE SmartWorld Ubiquitous Intelligence and Computing, Advanced and Trusted Computed, Scalable Computing and Communications, Cloud and Big Data Computing, Internet of People and Smart City Innovation, SmartWorld/SCALCOM/UIC/ATC/ CBDCom/IOP/SCI 2017 - Conference Proceedings, 1-8. doi: 10.1109/UIC-ATC.2017.8397495

Vitunskaite, M., He, Y., Brandstetter, T., \& Janicke, H. (2019). Smart cities and cyber security: Are we there yet? A comparative study on the role of standards, third party risk management and security ownership. Computers and Security, 83, 313-331. doi: 10.1016/j.cose.2019.02.009

Vranken, T., Sliwa, B., Wietfeld, C., \& Schreckenberg, M. (2019). Performance comparison of dynamic vehicle routing methods for minimizing the global dwell time in upcoming smart cities. IEEE Vehicular Technology Conference, 2018-August. doi: 10.1109/VTCFall.2018.8690655 
Wang, T., Liang, Y., Jia, W., Arif, M., Liu, A., \& Xie, M. (2019). Coupling resource management based on fog computing in smart city systems. Journal of Network and Computer Applications, 135, 11-19. doi: 10.1016/j.jnca.2019.02.021

Wei, Y., Wang, Y., Chang, Y., Shi, B., \& Shao, K. (2019). Research on the construction of "u-smart transportation system" under artificial intelligence technology. IOP Conference Series: Materials Science and Engineering, 490(4). doi: 10.1088/1757-899X/490/4/042002

What are the disadvantages of smart cities? Retrieved from https://www.quora.com/What-are-the-disadvantages-of-smart-cities

Xie, Q., \& Hwang, L. (2019). Security enhancement of an anonymous roaming authentication scheme with twofactor security in smart city. Neurocomputing, 347, 131-138. doi: 10.1016/j.neucom.2019.03.020

Xie, Y., Gupta, J., Li, Y., \& Shekhar, S. (2019). Transforming smart cities with spatial computing. IEEE International Smart Cities Conference, ISC2 2018. doi: 10.1109/ ISC2.2018.8656800

Yang, Z., \& Zhu, M. (2019). A dynamic prediction model of real-time link travel time based on traffic big data. Proceedings - 2019 International Conference on Intelligent Transportation, Big Data and Smart City, ICITBS 2019, 330-333. doi: 10.1109/ICITBS.2019.00087

Yu, M., Yang, Y., Chen, F., Zhu, F., Qu, J., \& Zhang, S. (2019). Response of agricultural multifunctionality to farmland loss under rapidly urbanizing processes in yangtze river delta, china. Science of the Total Environment, 66, 1-11.

Zanella, A., Bui, N., Castellani, A., Vangelista, L., \& Zorzi, M. (2014). Internet of things for smart cities. IEEE Internet of Things Journal, 1(1), 22-32. doi: 10.1109/ JIOT.2014.2306328

Zhang, Y., \& Pu, H. (2019). Environmental indicators of sustainable computing applications for smart city. Concurrency Computation, 31(9). doi: 10.1002/ cpe. 4751

Zhao, L., Wang, J., Liu, J., \& Kato, N. (2019). Routing for crowd management in smart cities: A deep reinforcement learning perspective. IEEE Communications Magazine, 57(4), 88-93. doi: 10.1109/MCOM.2019.1800603

Zheng, H., Chang, W., \& Wu, J. (2019). Traffic flow monitoring systems in smart cities: Coverage and distinguishability among vehicles. Journal of Parallel and Distributed Computing, 127, 224-237. doi: 10.1016/j. jpdc.2018.07.008

Zhu, Z., \& Liang, W. (2019). Congestion control strategy of distance education system based on TCP protocol. Proceedings - 2019 International Conference on Intelligent Transportation, Big Data and Smart City, ICITBS 2019, 485-488. doi: 10.1109/ICITBS.2019.00123

Zhuhadar, L., Thrasher, E., Marklin, S., \& de Pablos, P. O. (2017). The next wave of innovation - review of smart cities intelligent operation systems. Computers in Human Behavior, 66, 273-281. doi: 10.1016/j. chb.2016.09.030 